\title{
WHITE IBIS SIGHTING AT SHOAL LAKE, MANITOBA
}

\author{
C. CLIFF FINDLAY, Box 59, Shoal Lake, Manitoba. R0J 1 Z0
}

A telephone call at 9:00 a.m., 11 May 1991, advising me of a unique bird took Don and I to the farm of the Dutkywich brothers, at SW 35-16-24 W1, near Shoal Lake.

A white bird about $60 \mathrm{~cm}$ tall, with a red bare face, a long down-turned red bill and red legs was observed probing in grassy slough bottoms for food, "possibly frogs." This bird showed black wing tips only in flight, otherwise all other feathers were white.

Nelson Wyatt, Tony and Leonard Dutkywich, and Don and Cliff Findlay observed this bird at distances of 150-200 $\mathrm{m}$ for 20 minutes, with a 20 -power scope and $7 \times 50$ binoculars.

The Dutkywich brothers had seen the bird several times from 8-11 May flying from slough to slough. At about 9:45 a.m., 11 May, it flew off into a willow swamp and was not seen again.

With the National Geographic guide The Birds of Canada and the Audubon Society Field Guide to North American Birds in hand as we observed, we decided it had to be a White Ibis (Eudocimus albus). The red face, red down-curved bill and red legs indicated it was in full breeding plumage.

Godfrey in his 1986 edition of The Birds of Canada lists three records in Ontario, one in Quebec and Nova Scotia - all for summer and fall - and two for Newfoundland.

Could this be a first for Manitoba?

In early Egyptian writings one of the most usual symbols of divinity was a falcon on its perch, whilst in later dynasties it represented the king, who was regarded as allpowerful and descended from the gods. Dennis Bardens, 1987. Psychic Animals. Holt, N.Y. 